always a collection of named individuals, none of whom could ever sustain the fiscal burden of the state's debt, or the moral burden of the state's acts of violence' (p. 28). But this seems rather different from saying that the state 'is never to be identified with anyone or anything, in particular' (p. 37). This is not to deny the force of Runciman's point that it is terribly difficult to provide a phenomenological account of the state - or of money - and that scarcely anyone, anymore, asks questions like 'what is the state?' or 'what is money?' though these were once staples of political and economic thought. The point, rather, is that if such questions are worth trying to answer nowadays we should not expect them to be simple, and should expect them have some bearing on how we think about particular people, events and associations. Hence, Runciman's readiness to dismiss the latter at the outset seems to foreclose, unnecessarily, the most promising means to a better sense of the state as a lived reality, not just a legal fiction. Hence, too, my discomfort with the editorial decision to ignore intermediate associations, and their role in shaping, even constituting, state-citizen relations: this makes the state seem desperately abstract, and to make the fine historical articles in this volume unnecessarily inaccessible to those with more contemporary and theoretical concerns.

Annabelle Lever University College London, UK

\title{
Political Concepts
}

Richard Bellamy and Andrew Mason (eds.)

Manchester University Press, Manchester, 2003, viii $+245 p p$.

ISBN: 071905908 9/0 719059097.

\section{Political Thinkers: From Socrates to the Present}

David Boucher and Paul Kelly (eds.)

Oxford University Press, Oxford, 2003, xvi $548 p$.

ISBN: 0198781946.

Contemporary Political Theory (2005) 4, 87-90. doi:10.1057/palgrave.cpt.9300152

These are a worthwhile couple of books that a variety of readers are likely to find useful in their different ways. The first, Political Concepts, aims to provide introductory analyses of the political concepts that form the building blocks of political argument. As well as the target audience of textbook buying students, the book is deemed to be perfect 'for anyone approaching political theory for 
the first time'. It is a compendium of essays on 17 distinct, and sometimes overlapping, topics by different authors. In what follows, I don't want to name names - to pick fights or to confer honours.

What struck me most forcibly was the range of different approaches to the editors' brief of articulating the concept at hand. As I moved on from essay to essay, sometimes it was as though I was meeting work in a totally different academic genre from a previous contribution. In point of style, most but not all contributors wrote in plain clear prose. Some lapsed into technicalities as soon as serious argument got under way, and some wrote throughout for an audience familiar with the favoured technical argot. There was a fair amount of coy nudging and smart allusion by authors who envisaged that fellow professionals might be looking up their contributions and didn't want to seem too naïve.

Some authors took seriously the requirement that their work be accessible to newcomers to the discipline, outlining with care a range of well-known positions from contemporary discussions, setting up disputes and adjudicating them, or pointing towards suggestive solutions, in light of the author's own contribution to the recent literature. Other authors presented an abstract and technically sophisticated digest of modern theoretical work that would be hard to master by one who wasn't already an adept. The chief interest with this kind of work was the novel configuration of established positions. Other authors, as I read their contributions, didn't seem to be clarifying the concepts in any recognizably philosophical or theoretical fashion; rather they were unravelling the ideological strands of modern political discourse, exposing to plain gaze what Bentham called sinister interests.

The editors do not aspire to present a complete set of 'concepts', but I want to be niggardly and point to an omission. There is no essay on the issue, central to modern political theory, of distributive justice. There is a very technical discussion of equality of opportunity, a 'blow the gaff' essay on problems of welfare and social exclusion, and an introductory survey of problems concerning international justice, but there is nothing on the vexed issue of the metric of equality, or the merits and demerits of egalitarianism.

Political Thinkers is a one (lengthy) volume of the Plato to NATO variety (in fact from the Sophists to Foucault), collecting together essays on 28 different thinkers or groups of thinkers. As with the topics of Political Concepts, there's bound to be a measure of controversy over the selection of members of the pantheon. I would have made space for Kant, but otherwise find the selection well-judged from the perspective of an English-speaking readership. The contributors are experts, all working conscientiously to a highly specific brief: each essay has an abstract, a brief biography of the philosopher(s) discussed, details of key texts and editions used, a statement of key ideas, notes and guidance on further reading as well as the main discursive material. 
Controversial readings abound, but these are clearly signalled and opposing views are stated in the text or notes. I was pleasantly surprised to find no commentators egregiously grinding their own axe to the disadvantage of the innocent reader.

Is a collection of independent specialist authors better than a single authored monograph? On balance, I suspect that the two approaches have their own merits and defects. A collection doesn't have the connecting passages or the interpretative themes that a single author can advance over a number of chapters. Appropriate mention of minor figures is difficult to ensure and thematic historical episodes (I'm thinking, for example, of Plamenatz's splendid discussion of the emergence of doctrines of toleration) cannot easily be integrated. These obvious points made, one very strong advantage of the edited collection should be stressed. Readers of reference works in political philosophy are not simply looking for the low-down on the high-ups, for a quick crib; there is plenty of this stuff on the Internet. They want to see, or deserve to get, commentators - interpreters and critics - who can display, at a high level, the skills of the professional discipline. There are many such skills, many different balancings of skills across academic exercises, many different styles (literary, theoretical, philosophical) with which these subjects can be advanced. So in consequence, it's a good thing, as both of the volumes under consideration attest, if the student ('common reader', undergraduate, postgraduate, colleague) is exposed to a wide variety of expert approaches. And even the not-so-expert contribution has its pedagogical merits, as teachers will no doubt point out.

I said I would name no names, but that was for purposes of discussion. I should record the contributors to the different volumes. They deserve an accolade. Their efforts in these splendid books are not likely to count for much in CVs or in research assessment exercises, so let me list them (and their subjects) in a roll of honour for employing their expertise in the cause of general education and enlightenment.

Political Concepts: Ian Carter (Liberty), Catriona McKinnon (Rights: Their Basis and Limits), Andrew Mason (Social Justice: the Place of Equal Opportunity), Rex Martin (Political Obligation), Ciarán O'Kelly (Nationalism and the State), Emilio Santoro (Crime and Punishment), Bill Jordan (Welfare and Social Exclusion), Alan Cromartie (Legitimacy), David Owen (Democracy), Richard Bellamy (The Rule of Law), Judith Squires (Public and Private), Keith Graham (Community: Individuals Acting Together), Jonathan Seglow (Multiculturalism), Terrell Carver (Gender), Andrew Vincent (Green Political Theory), David Boucher (International Justice), Anthony Coates (Just War).

Political Thinkers: Peter Nicholson (The Sophists), Fred Rosen (Socrates), C.D.C. Reeve (Plato), Tony Burns (Aristotle), Jean Bethke Elshtain (St. Augustine), Joseph Canning (Aquinas), Cary J. Nederman (Marsilius of 
Padua), Joseph V. Femia (Machiavelli), Deborah Baumgold (Hobbes), Jeremy Waldron (Locke), Paul Kelly (Hume; Bentham; J.S. Mill on Liberty), Yoshie Kawade (Montesquieu), David Boucher [again] (Rousseau; Oakeshott), Terence Ball (see p. 18 for an editorial 'oops') (Federalist Papers), Carole Pateman (Wollstonecraft), Cheryl Welch (Tocqueville), Jennifer Ring (J.S. Mill on the Subjection of Women), Alan Patten (Hegel), Laurence Wilde (early Marx), Paul Thomas (Marx and Engels), Nathan Widder (Nietzsche), Kenneth Baynes (Habermas), Rex Martin (again) (Rawls), Paul Patton (Foucault).

Dudley Knowles University of Glasgow, UK

\author{
Republicanism in the Modern World \\ John W. Maynor \\ Polity, Cambridge, 2003, $x+230 p p$. \\ ISBN: $0745628079 / 0745628087$.
}

Contemporary Political Theory (2005) 4, 90-92. doi:10.1057/palgrave.cpt.9300158

This book aims to present a version of republicanism appropriate to the moral and cultural diversity of the modern world, based on the account of freedom as non-domination developed notably by Pettit. This sees politics as addressing domination: the threat of arbitrary interference, rather than interference per se (as in negative conceptions of freedom), or realizing the political nature of citizens in politics (as in positive conceptions of freedom). It has been taken to lead to an instrumental or neo-Roman republicanism free of the alleged dangers inherent in the 'Athenian' participatory republicanism of Rousseau, Arendt and others. While Maynor takes Pettit's account as 'a start that signals the direction that modern republicanism must take' (p. 32), and works systematically through the implications of freedom as non-domination, he advances an independent account of republicanism that, as it turns out, is not as purely instrumental as such a starting point might suggest. Already in the first chapter, Maynor shows that the contrasts between ancient and modern liberty, Athenian and instrumental republicanism, are not as sharp as often assumed, and reminds us, for example, of Constant's belief that the two kinds of liberty need to be combined, and that institutions need to bring about the moral education of citizens.

The author identifies and elaborates in some detail on what he sees as three central pillars of republican non-domination: democratic contestatory institutions, civic education and the social norms that prevail in society. Institutions are designed to disperse and balance power in order to minimize potential 